\title{
Lettuce and marigold intercropping: crops productivity and marigold's flavonoid content
}

\author{
Consórcio entre alface e calêndula: produtividade \\ das culturas e teor de flavonóides em calêndula
}

\author{
Maira Christina Marques Fonseca ${ }^{\mathrm{I}^{*}}$ Maria Aparecida Nogueira Sediyama ${ }^{\mathrm{I}}$ \\ Filipe Pereira Giardini Bonfim ${ }^{\text {II }}$ Rosana Gonçalves Rodrigues das Dores ${ }^{\text {III }}$ \\ Melina Guimarães Gonçalves ${ }^{I V}$ Adalgisa Leles do Prado ${ }^{\text {IV }}$ Iza Paula de Carvalho Lopes ${ }^{\text {IV }}$
}

\section{ABSTRACT}

Intercropping of vegetables and medicinal plants might produce favorable interactions for both crops, resulting in increased production and profit per unit area. It is known that active compounds can change because of several factors, including the cropping system. Therefore, the goal of this study was to evaluate the effect of intercropping of lettuce and marigold on the productivity of these crops and on the flavonoid content of marigold flowers. The experiment was conducted in the experimental area of EPAMIG in Oratorios-MG. Treatments consisted of lettuce + marigolds intercropping between rows, lettuce + marigold intercropping between plants, and monocultures of each species. Spacing was $0.3 \times 0.3 \mathrm{~m}$. The experimental design consisted of randomized blocks with ten repetitions. Harvest of lettuce and marigold flowers started 45 days after transplantation (DAT) and extended up to 72 DAT for marigolds. Lettuce and marigold intercropping appears feasible because lettuce production did not differ between the monoculture and intercropped cultivations, and marigold productivity was higher when intercropped with lettuce. No change in the flavonoid (active chemicals of medicinal interest) content in the floral capitula of marigolds was observed.

Key words: Lactuca sativa L., Calendula officinalis $L$. , crop association, land equivalent ratio, medicinal plants.

\section{RESUMO}

$O$ cultivo consorciado entre hortaliças e plantas medicinais pode promover interação benéfica entre as duas culturas, resultando em aumento na produção e no lucro por unidade de área. Sabe-se também que os principios ativos podem ser alterados por vários fatores, incluindo o sistema de cultivo. Dessa forma, o objetivo do presente trabalho foi avaliar o efeito do consórcio entre alface e calêndula na produtividade destas culturas e no teor de flavonoides em flores de calêndula. $O$ experimento foi conduzido na área experimental da EPAMIG, em Oratórios$M G$. Os tratamentos consistiram em: alface + calêndula entre linhas, alface + calêndula entre plantas e os monocultivos de alface e de calêndula. $O$ espaçamento utilizado foi de 0,3x0,3m. $O$ delineamento experimental foi em blocos casualizados com dez repetições. A colheita de alface e das flores de calêndula iniciou-se 45 dias após o transplantio (DAT), sendo a colheita de calêndula estendida até os 72 DAT. O consórcio entre alface e calêndula é viável, pois a produção da alface é semelhante entre sistemas consorciados e cultivo solteiro, e a produtividade da calêndula é maior quando consorciada com a alface, não havendo alteração no teor de flavonoides (princípio ativo de interesse medicinal) dos capitulos florais de calêndula.

Palavras-chave: Calendula officinalis L., Lactuca sativa L., associação de culturas, índice de equivalência de área, plantas medicinais.

\section{INTRODUCTION}

Intercropping has aroused the attention of researchers and farmers primarily because of the intriguing aspects of inherent ecological interactions, potential arrangements management options, and potential economic viability. In addition, it is an applicable and accessible technology that results in few environmental impacts compared to those of monocultures (REZENDE et al., 2002). This cultivation system has employed by family farmers

\footnotetext{
'Empresa de Pesquisa Agropecuária de Minas Gerais (EPAMIG), 36571-000, Viçosa, MG, Brasil. E-mail: maira@epamig.br. ${ }^{*}$ Corresponding author.

"Faculdade de Ciências Agronômicas (FAC), Universidade Estadual Paulista "Julio de Mesquita Filho" (UNESP), Botucatu, SP, Brasil.

IIIUniversidade Federal de Ouro Preto (UFOP), Ouro Preto, MG, Brasil.

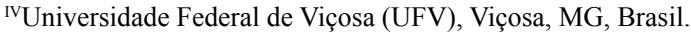


for whom it led to increased productivity, product diversification (LIRA, 2013), and improved utilization of arable land and labor resources (CAETANO et al., 2001; MONTEZANO \& PEIL, 2006).

Furthermore, intercropping might promote increased biological efficiency of associated crops, and changes in growth cycles and composition of intercropped species (SOBKOWICZ \& TENDZIAGOLSKA, 2005; MONTEZANO \& PEIL, 2006). However, most studies on intercropping only address horticultural species (CECÍLIO FILHO \& MAY, 2002; BEZERRA NETO et al., 2003). There are few studies on intercropping of vegetables and medicinal plants (MAIA et al., 2008; MORAES et al., 2008; CARVALHO et al., 2009).

Given the recent increase in appreciation for the value of vegetables, which resulted from the search for healthier food, and the incentive of production caused by the use of medicinal plants for public health by regulatory agencies (RODRIGUES \& DE SIMONI, 2010), two species of national economic importance were selected for this study: lettuce and marigold.

Lettuce (Asteraceae) is the most important economic leafy vegetable in the country, being cultivated in almost all regions of Brazil (CARVALHO FILHO et al., 2009). Its consumption is related to the ease acquisition and affordable cost. In addition, it contributes to a healthy diet as a source of vitamins (A and C) and minerals (CAETANO et al., 2001).

Marigold (Calendula officinalis

L.) belongs to the same family as lettuce, and it is cultivated in many regions of Brazil. Its capitula are traded worldwide and used for ornamentation, as well as for medicinal and cosmetic purposes. This species was selected by the Ministry of Health and is present in the National List of Medicinal Plants of Interest for SUS (RENISUS) (BRASIL, 2009).

The active ingredients in marigolds are extracted from its flowers (ALONSO, 2008; PAGNANO et al., 2008). Among these, flavonoids rutin and quercetin stand out (RODRIGUES et al., 2004), and are responsible for its anti-inflammatory activities. Flavonoid levels should be higher than $0.4 \%$ in the raw plant material (flowers) to exert therapeutic effects (FARMACOPÉIA BRASILEIRA, 2001; BRASIL, 2011)

Many factors can influence the contents of secondary metabolites (GOBBONETO \& LOPES, 2006), especially flavonoids.
In marigold, it was found that the timing of harvest could alter the total levels of flavonoids (FONSECA et al., 2014). Therefore, it is very important to identify the growth and harvest conditions that provide the highest levels of raw materials that meet the standards recommended by the Brazilian Pharmacopeia.

Given the increasing demand for research that elucidates the best production practices, the goal of this study was to verify the viability of intercropping of lettuce and marigold based on the productivity of the two crops and the level of flavonoids in marigold (the active ingredient of interest of the Brazilian Unified Health System - SUS).

\section{MATERIALS AND METHODS}

This study was conducted in field conditions at the experimental farm of the Agricultural Research Company of Minas Gerais (in Portuguese, Empresa de Pesquisa Agropecuária de Minas Gerais) (Oratórios-MG): coordinates $20^{\circ} 25^{\prime} 49^{\prime \prime} \mathrm{S}$ and $42^{\circ} 48^{\prime} 20^{\prime \prime} \mathrm{W}$, at $422 \mathrm{~m}$ of altitude. Average maximum annual temperature was of $21.8^{\circ} \mathrm{C}$ and average minimum was of $19.5^{\circ} \mathrm{C}$. Average annual precipitation was 1,250mm (CUNHA et al., 2000).

The soil of the cultivated area, classified as cambic red-yellow acrisol, had the following characteristics: $\mathrm{pH}($ water 1:2.5) $=5.1 ; \mathrm{P}($ Mehlich 1$)=$ $9.9 \mathrm{mg} \mathrm{dm}^{-3} ; \mathrm{P}$ (remainder) $=30.3 \mathrm{mg} \mathrm{L}^{-1} ; \mathrm{K}=71 \mathrm{mg} \mathrm{dm}^{-3}$; $\mathrm{Ca}=2.00 \mathrm{cmol} \mathrm{dm}_{\mathrm{c}}^{-3} ; \mathrm{Mg}=0.9 \mathrm{cmol}_{\mathrm{c}} \mathrm{dm}^{-3} ; \mathrm{Al}=0.1 \mathrm{cmol}_{\mathrm{c}}$ $\mathrm{dm}^{-3} ; \mathrm{H}+\mathrm{Al}=3.47 \mathrm{cmol} \mathrm{dm}^{-3} ; \mathrm{SB}=3.08 \mathrm{cmol} \mathrm{dm}^{-3} ; \mathrm{t}=$ $3.18 \mathrm{cmol}_{\mathrm{c}} \mathrm{dm}^{-3} ; \mathrm{m}=0 \%$; $\mathrm{T}=6.55 \mathrm{cmol} \mathrm{dm}_{\mathrm{c}}^{-3} ; \mathrm{V}=47 \%$; and organic matter $=3.3 \mathrm{dag}_{\mathrm{kg}^{-1}}$.

The preparation of the soil consisted of harrowing, raising beds, and treating with organic fertilizer using $40 \mathrm{t} \mathrm{ha} \mathrm{ha}^{-1}$ of organic compost (sugarcane bagasse + cow dung + coffee leaves). Characteristics of the fertilizer were $\mathrm{N}=19.6 ; \mathrm{P}=$ $3.5 ; \mathrm{K}=8.0 ; \mathrm{Ca}=12.3 ; \mathrm{Mg}=3.5 ; \mathrm{S}=3.5 \mathrm{~g} \mathrm{~kg}^{-1} ; \mathrm{C}$. org. $=12.18 \mathrm{dag} \mathrm{kg}^{-1}$ and, $\mathrm{C} / \mathrm{N}=6.25$.

Treatments consisted of the following intercropping: lettuce + marigold between rows, lettuce + marigold between plants, and monocultures of each species. The experimental design was a randomized block with ten repetitions, where each experimental plot was formed by four rows and 16 plants. Spacing was of $0.3 \mathrm{~m} \times 0.3 \mathrm{~m}$ for both species.

The marigold (cultivar 'Dobrada Sortida') and lettuce (cultivar 'Verônica') 
seedlings were sown in trays of 200 cells containing the commercial Plantmax ${ }^{\circledR}$ substrate and transplanted to the cultivation area 28 days after planting when the seedling had four welldefined leaves. During the cultivation cycle, irrigation was conducted by micro-aspersion and weeding has done by hand with a hoe. Lettuce was harvested at 45 days after transplant (DAT), when plants were fully developed. The following characteristics were evaluated: height and diameter $(\mathrm{cm})$ of the head, wet and dry mass of the aerial portion, and number of leaves per plant. Harvest of the marigold's flowers began at 45 DAT and continued until 72 DAT. Five harvests were completed, and the dry mass and total flavonoid content of the flowers were determined. At 72 DAT, the wet mass of the aerial portion and height of marigold plants were also measured.

The spectrophotometry method adapted by NABAVI et al. (2008) was used to determine the total flavonoid content of the marigold's flowers.

Intercropping (WILLEY, 1979; GLIESSMAN, 2000) was conducted by determining the land equivalent ratio (LER), using the formula: $\mathrm{LER}=(\mathrm{Cc} / \mathrm{Cs})+(\mathrm{Ac} / \mathrm{As})$, where $\mathrm{Cc}$ is the productivity of the intercropped marigold, Ac is the productivity of the intercropped lettuce, $\mathrm{Cs}$ is the productivity of the marigold monoculture, and As is the productivity of the lettuce monoculture. The data obtained were subjected to analysis of variance (ANOVA) and the averages were compared using Tukey's test at $5 \%$ probability, by using SAEG (2007) software.

\section{RESULTS AND DISCUSSION}

No statistical differences were observed for lettuce when comparing monoculture and intercropped crops and the following averages values were obtained for the characteristics analyzed: wet $(300.78 \mathrm{~g})$ and dry mass of leaves
$(21.18 \mathrm{~g})$, diameter $(37.9 \mathrm{~cm})$, number of leaves (30), and length of the stem $(11.7 \mathrm{~cm})$. Similar results were reported by MOTA et al. (2011) when lettuce (L. sativa) and marcela (Achyrocline satureioides) were intercropped. Basil (Ocimum basilicum) and lettuce (L. sativa) intercropping (VIEIRA et al., 2012), as well as intercropping of carrots (Daucus carota) and marigolds (JANKOWSKA, 2012) did not affect productivity. Thus, the results obtained in this study showed that lettuce and marigold intercropping is viable because it did not compromise vegetable development or productivity.

However, in marigold-intercropped cultivations, significant differences were observed in the following parameters: diameter of the aerial part (DIAM), plant height (PH), dry mass of floral capitula (DMC), and wet mass of the aerial part (DMAP) (Table 1). Similar results were reported by CARVALHO \& OLIVEIRA (2011) for cabbage (Brassica oleracea var. capitata) and lemongrass (Cymbopogon citratus) intercropping, and for cabbage and wormwood (Artemisia absinthium) intercropping, which increased productivity of these medicinal species. Results obtained indicated that intercropping is advantageous because it allowed better marigold tillering, and consequently, the development of a greater number of floral stems after the lettuce was harvested.

Higher values for marigold plant height were observed in marigold and lettuce intercropping when compared to the marigold monoculture (Table 1). A similar result was observed by CARVALHO \& OLIVEIRA (2011) in cabbage and wormwood (A. absinthium) intercropping, where the medicinal species displayed greater height in intercropped cultivations compared to monocultures.

Both the dry mass of flowers and the diameter of marigold plants showed a similar behavior. Marigold and lettuce intercropping

Table 1 - Diameter of the aerial part (DIAM), plant height (PH), dry mass of flowers (DMF), wet mass of the aerial part (WMAP) and flavonoid content (FC) of marigold plants subjected to two cultivation systems: intercropped cultivations with lettuce in two types of arrangements (intercropping between plants and between rows) and monoculture.

\begin{tabular}{|c|c|c|c|c|c|}
\hline Treatments & DIAM $(\mathrm{cm})$ & $\mathrm{PH}(\mathrm{cm})$ & $\operatorname{DMF}(\mathrm{g})$ & WMAP $(g)$ & $\mathrm{FC}(\% \mathrm{w} / \mathrm{w})$ \\
\hline Marigold: intercropped w/ lettuce between rows & $39.76 \mathrm{a}$ & $50.46 \mathrm{a}$ & $12.77 \mathrm{a}$ & $420.0 \mathrm{a}$ & 0.57 \\
\hline Marigold: intercropped w/ lettuce between plants & $38.46 \mathrm{ab}$ & $49.26 \mathrm{a}$ & $12.57 \mathrm{ab}$ & $384.0 \mathrm{a}$ & 0.56 \\
\hline Marigold: monoculture & $35.40 \mathrm{~b}$ & $42.27 \mathrm{~b}$ & $8.04 \mathrm{~b}$ & $252.0 \mathrm{~b}$ & 0.56 \\
\hline
\end{tabular}

Means followed by the same letter in a column do not differ from each other by Tukey's Test at $5 \%$ probability.

Ciência Rural, v.46, n.9, set, 2016. 
between rows was beneficial in comparison to the marigold monoculture. Regarding the dry mass of the aerial part, there were no differences between the marigold and lettuce intercropping between rows and between plants. However, both developed better than the marigold monoculture (Table 1). Because lettuce was harvested at 45 DAT and the harvest of marigold flowers was extended until 72 DAT, the medicinal species sprouted more because of the greater space available and the absence of competition for water and nutrients.

The total flavonoid content in marigold's flowers was not statistically different (Table 1) and within the recommended standards (greater than $0.4 \% \mathrm{p} / \mathrm{p}$ ) (FARMACOPÉIA BRASILEIRA, 2001; BRASIL, 2011). Consistency in the levels of this active ingredient (mean of $0.56 \%$ ) confirmed the viability of marigold and lettuce intercropping. A similar result was reported by OLIVEIRA et al. (2011) who did not observe changes in the content and chemical composition of the essential oil of peppermint (Mentha piperita), in a peppermint and chives (Allium schoenoprasum L.) intercropping.

In relation to lettuce productivity, no significant differences were observed between intercropped marigold cultivation and the monoculture (Table 2). Good lettuce productivity was obtained in both intercropped cultivations and monoculture. These productivities were superior to the levels described by AGRIANUAL

Table 2 - Lettuce and marigold productivity in intercropping systems with two types of arrangements (intercropping between plants and between rows) and monoculture.

\begin{tabular}{lc}
\hline Treatments $^{*}$ & Productivity $\left(\mathrm{kg} \mathrm{ha}^{-1}\right)^{* *}$ \\
\hline $\begin{array}{l}\text { Lettuce: intercropped w/ marigold } \\
\text { between plants }\end{array}$ & $34,250.00 \mathrm{a}$ \\
$\begin{array}{l}\text { Lettuce: intercropped w/ marigold } \\
\text { between rows }\end{array}$ & $34,320.00 \mathrm{a}$ \\
Lettuce: monoculture & $38,850.00 \mathrm{a}$ \\
$\begin{array}{l}\text { Marigold: intercropped w/ lettuce } \\
\text { between plants }\end{array}$ & $42,770.00 \mathrm{a}$ \\
$\begin{array}{l}\text { Marigold: intercropped w/lettuce } \\
\text { between rows }\end{array}$ & $46,660.00 \mathrm{a}$ \\
Marigold: monoculture & $28,110.00 \mathrm{~b}$ \\
\hline
\end{tabular}

*In intercropping, the number of lettuce plants corresponds to half of those referring to monoculture.

${ }^{* *}$ Means followed by the same letter do not differ from each other by the Tukey's Test at 5\% probability.
(2006) for lettuce monocultures, which suggests that lettuce and marigold intercropping is mutually beneficial. Another advantage of this intercropping is to allow harvest of lettuce before that of marigolds, thus improving the cultivation area and the tillering space for marigold plants.

The productivity of intercropped marigolds between rows or between lettuce plants was greater when compared to marigold monoculture, by 1.52 and 1.66 fold, respectively (Table 2). This observation indicates that, besides other cultivation conditions, the choice of intercropped species might affect productivity, and optimize the use of all production factors of the environment, benefiting all species under cultivation (MAIA et al., 2008). For example, given that the initial growth of lettuce is slower in the first 30 DAT, there was no competition with the development of marigold plants, which favored the initial development of the medicinal species and the production of flowers. CECÍLIO FILHO \& MAY (2002) reported that radish and lettuce intercropping increased the production of tuberous roots when compared to monocultures, without affecting lettuce productivity, when radishes were planted up to 7 days after the lettuce.

The Land Equivalent Ratio (LER) is defined as the relative area required for polycultures to afford the same yield as monocultures (ALTIERI et al., 2003). Lettuce and marigold intercropping exhibited a LER greater than 1.0 (Table 3); thus, showing the viability of the cultivation systems between rows and between plants. However, intercropping between rows is recommended because of its ease of implementation in the field.

\section{CONCLUSION}

Lettuce and marigold intercropping between rows is viable because it did not alter lettuce productivity as compared to monocultures, and it favored the productivity of marigolds without affecting flavonoid content.

Table 3 - Lettuce and marigold monoculture and intercropping land equivalent ratios (LER), in two arrangements (intercropping between plants and between rows).

\begin{tabular}{ll}
\hline Arrangements & LER \\
\hline Lettuce intercropped with marigold between plants & 2.40 \\
Lettuce intercropped with marigold between rows & 2.54 \\
\hline
\end{tabular}




\section{ACKNOWLEDGEMENTS}

We thank Conselho Nacional de Desenvolvimento Científico e Tecnológico (CNPq) and Fundação de Amparo a Pesquisa do Estado de Minas Gerais (FAPEMIG) for financial support.

\section{REFERENCES}

ALONSO, J.R. Fitomedicina: curso para profissionais da área da saúde. São Paulo: Pharmabooks, 2008. 195p.

ANUÁRIO DA AGRICULTURA BRASILEIRA (AGRIANUAL) 2006. São Paulo: Agra FNP Pesquisas LTDA, 2006. p.148, 255 e 334.

ALTIERI, M.A. et al. O papel da biodiversidade no manejo de pragas. Ribeirão Preto: Holos, 2003. 226p.

BEZERRA NETO, F. et al. Agroeconomic performance of carrot $\mathrm{x}$ looseleaf lettuce intercrops in two strip arrangements. Horticultura Brasileira, v.21, p. 635-641, 2003. Available from: $<$ http://www.scielo.br/pdf/hb/v21n4/19428.pdf >. Accessed: May 10, 2016. doi: 10.1590/S0102-05362003000400012.

BRASIL. Ministério da Saúde. Direção de Administração e Finanças. Secretaria de Ciência, Tecnologia e Insumos Estratégicos. RENISUS - Relação Nacional de Plantas Medicinais de Interesse ao SUS, 2009. 1p. Available from: $<$ http://portalsaude. saude.gov.br/index.php/cidadao/principal/agencia-saude/noticiasanteriores-agencia-saude/3487-ms-elabora-relacao-de-plantasmedicinais-de-interesse-ao-sus>. Accessed: May 10, 2016.

BRASIL. Formulário de fitoterápicos da farmacopeia brasileira. Brasília, 2011. 126p.

CAETANO, L.C.S. et al. A cultura da alface: perspectivas, tecnologias e viabilidade. Brasília: ANVISA / Niterói: PESAGRORIO, 2001. 23p. (Documento 78).

CARVALHO FILHO, J.L.S. et al. Tolerance to precocious flowering and commerical traits of F4 progenies of hybrid Regina 71 x Salinas 88 lettuce. Acta Scientiarum Agronomy, v.31, p.3742, 2009. Available from: <http://periodicos.uem.br/ojs/index. php/ActaSciAgron/article/view/6607>. Accessed: May 10, 2016. doi: 10.4025/actasciagron.v31i1.6607.

CARVALHO, L.M. et al. Yield of tomato in monocrop and intercropping with aromatics plants. Horticultura Brasileira, v.27, p.458-464, 2009. Available from: <http://www.scielo.br/ $\mathrm{pdf} / \mathrm{hb} / \mathrm{v} 27 \mathrm{n} 4 / 10 . \mathrm{pdf}>$. Accessed: may 10, 2016. doi: 10.1590/ S0102-05362009000400010.

CARVALHO, L.M.; OLIVEIRA, I.R. Consorciação de repolho com espécies aromáticas. Aracaju: EMBRAPA, 2011. 13p. (Comunicado Técnico, 113).

CECÍlIO FILHO, A.B.; MAY, A. Lettuce and radish productivity in intercropping systems as influenced by starting time and row spacings. Horticultura Brasileira, v.20, p.501504, 2002. Available from: <http://www.scielo.br/pdf/hb/ v25n1/a04v25n1.pdf $>$. Accessed: May 10, 2016. doi: 10.1590/ S0102-05362002000300021.

CUNHA, T.J.F. et al. Influence of the pedological differentiation on the development of rubber-tree cultivation in the state of Minas Gerais, Brazil. Pesquisa Agropecuária Brasileira, v.35, p.145-155, 2000. Available from: <http://www.scielo. br/scielo.php?pid=S0100-204X2000000100017\&script $=$ sci abstract\&tlng $=\mathrm{pt}>$. Accessed: May 10, 2016. doi: 10.1590/ S0100-204X2000000100017.

FARMACOPÉIA BRASILEIRA. 4.ed. São Paulo: Atheneu, 2001. Parte II. Fascículo 3. Monografia 134.

FONSECA, M.C.M. et al. Influência do horário de colheita no teor de flavonóides em calêndula. Horticultura Brasileira, v.31, p.S2592-S2596, 2014. Available from: $<$ http://www.abhorticultura.com.br/eventosx 2/eventosx/ ViewTrabalho.aspx idtrabalho $=9378 \&$ idevento $=7 \&$ tipo $=$ TRABALHOS>. Accessed: May 16, 2016. doi: 10.1590/ S0102-05361999000100001

GOBBO-NETO, L.; LOPES, N.P. Plantas medicinais: fatores de influência no conteúdo de metabólitos secundários. Química Nova, v.30, p.374-381, 2007. Available from: $<$ http://quimicanova.sbq.org.br/imagebank/ pdf/Vol30No2_374_25-RV05289.pdf >. Accessed: may 16, 2016. doi: $10.1590 / \mathrm{S} 0100-40422007000200026$.

GLIESSMAN, S.R. Agroecologia: processos ecológicos em agricultura sustentável. Porto Alegre: UFRGS, 2000. 653p.

JANKOWSKA, B. Effect of intercropping carrot (Daucus carota 1.) with french marigold (Tagetes patula nana L.) and pot marigold (Calendula officinalis L.) on the occurrence of some pestsand quality of carrot yield. Acta Agronomica, v.65, p.133-138, 2012.

LIRA, J.L.C.B. Produtividade, índice de equivalência de área e incidência de espontâneas em cultivo consorciado de alface. 2013. 31f. Monografia em Agronomia - Faculdade de Agronomia e Medicina Veterinária, Universidade de Brasília, DF.

MAIA, J.T.L.S. et al. Produção de alface e cenoura em cultivo solteiro e consorciado com manjericão e hortelã. Revista Brasileira de Agroecologia, v.3, p.58-64, 2008. Available from: <http://www.aba-agroecologia.org.br/revistas/index.php/ rbagroecologia/article/view/6819>. Accessed: May 16, 2016. doi: $10.5039 /$ agraria.v4i3a9.

MONTEZANO, E.M.; PEIL, R.M.N. Sistemas de consórcio na produção de hortaliças. Revista Brasileira Agrociência, v.12, p.129-132, 2006. Available from: <https://periodicos.ufpel. edu.br/ojs2/index.php/CAST/article/viewFile/4502/3376>. Accessed: May 16, 2016. doi: 10.18539/CAST.V12I2.4502.

MORAES, A.A. et al. Produção da capuchinha em cultivo solteiro e consorciado com os repolhos verde e roxo sob dois arranjos de plantas. Ciência Agrotécnica, v.32, p.11951202, 2008. Available from: <http://www.scielo.br/pdf/ cagro/v32n4/a24v32n4.pdf $>$. Accessed: May 16, 2016. doi: 10.1590/S1413-70542008000400024

MOTA, J.H. et al. Crescimento e produção de alface e marcela em cultivo solteiro e consorciado. Acta Scientiarum Agronomy, v.33, p.269-273, 2011. Available from: <http:// www.scielo.br/pdf/asagr/v33n2/11.pdf>. Accessed: May 16, 2016. doi: 10.4025/actasciagron.v33i2.4426.

NABAVI, S.M. et al. Determination ofantioxidant activity, phenol and flavonoids content of Parrotia persica Mey. Pharmacologyonline, v.2, p.560-567, 2008. Available from: 
$<$ http://pharmacologyonline.silae.it/files/archives/2008/ vol2/53_Ebrahimzadeh.pdf $>$. Accessed: May 16, 2016.

OLIVEIRA, A.R.M.F. et al. Potencial alelopático, produção de biomassa e óleo essencial de alevante (Mentha x piperita var. citrata (Ehrh.) Briq.) em cultivo solteiro e consorciado com cebolinha (Allium schoenoprasum L.) e chicória (Chicorium endivia L.). Revista Brasileira de Biociências, v.9, p.497-501, 2011. Available from: <http://www.ufrgs.br/seerbio/ojs/index.php/ rbb/article/view/1944>. Accessed: May 16, 2016.

PAGNANO, L.O. et al. Morfometria de fibloblastos e fibrócitos durante o processo cicatricial na pele de coelhos da raça Nova Zelândia Branco tratados com calêndula. Ciência Rural, v.38, n.6, p.1662-1666, 2008. Available from: <http://www.scielo.br/pdf/ cr/v38n6/a26v38n6.pdf>. Accessed: May 16, 2016. doi: 10.1590/ S0103-84782008000600026.

REZENDE, B.L.A. et al. Consorciação de alface e rabanete em diferentes espaçamentos e épocas de estabelecimento do consórcio, no inverno. Horticultura Brasileira, v.20, n. 2, p.S1-S4, 2002. Available from: <http://www.abhorticultura. com.br/biblioteca/arquivos/Download/Biblioteca/42_041.pdf>. Acessed: May 16, 2016.

RODRIGUES, P.O. et al. Influência de diferentes sistemas de solventes no processo de extração de Calendula officinalis L. (Asteraceae). Acta Farmaceutica Bonaerense, v.23, p.27-31,
2004. Available from: < http://www.latamjpharm.org/trabajos/23/1/ LAJOP_23_1_1_4_29V9O46162.pdf>. Accessed: May 16, 2016.

RODRIGUES, A.G.; DE SIMONI, C. Plantas medicinais no contexto de políticas públicas. Informe Agropecuário, v.31, p.7-12, 2010 .

SAEG. Sistema para análise estatística. Versão 9.1. Viçosa, MG: Fundação Artur Bernardes. 2007.

SOBKOWICZ, P.; TENDZIAGOLSKA, E. Competition and yield in mixture of oats and wheat. Journal of Agronomy and Crop Science, v.191, p.377-385, 2005. Available from: $<$ http://onlinelibrary. wiley.com/doi/10.1111/j.1439-037X.2005.00169.x/epdf>. Accessed: May 16, 2016. doi: 10.1111/j.1439-037X.2005.00169.x.

VIEIRA, M.C. et al. Consórcio de manjericão (Ocimum basilicum L.) e alface sob dois arranjos de plantas. Revista Brasileira de Plantas Medicinais, v.14, p.169-174, 2012. Available from: <http://www.scielo.br/pdf/rbpm/ v14nspe/08.pdf>. Accessed: May, 16, 2016. doi: 10.1590/ S1516-05722012000500008.

WILLEY, R.W. Intercropping - Its importance and research needs. Cap 1. Competition and yield advantages. Field Crop Abstracts, v.32, p.1-13, 1979. Available from: $<$ http://krishikosh. egranth.ac.in/HD/common/split_document.jsp?doc=MPKV-987. pdf1/2056350/1/>. Accessed: May 17, 2016. 